\title{
Musical Stress Management for Women Entrepreneurs
}

\author{
Dr. Shveata Misra \\ Ph.D Psychology of Music, \\ Banasthali University, Rajasthan
}

\author{
Prof. Ina Shastri \\ H.O.D Music Department, \\ Banasthali University, Rajasthan
}

\begin{abstract} and are exploring new vistas of economic participation as entrepreneurs. They at times get largely discouraged by their own family members and peers who cannot see a woman's worth. In the last few decades there have been many extensive literatures on work stress but among women entrepreneurs, knowledge about coping with work stress is still inadequate in comparison. The present study is designed to extend the influential sources on stress among women entrepreneurs and how music can help to heal stress amongst them.
\end{abstract}

Today's global economic development has brought and emotional responses that occur when the many changes in the lives of women. The women in requirements of the business or job do not match the today's time have broken away from the beaten track capabilities, resources or needs of the entrepreneurs.

Keywords: Music, Responsibilities, Management, Women Entrepreneurs

\section{Introduction}

Entrepreneur is someone who is a risk taker, innovative, organizing and coordinating; According to a dictionary meaning "entrepreneur is a person who start a business and also provides employment to other" Entrepreneur is a multidimensional economic factor which tends a person to organize the business of his own and to run profitably using all the qualities of leadership, decision making and managerial calibre etc. Both men entrepreneur and women entrepreneur struggles to stand or face the dark side of the entrepreneurship. But when we specifically talk about women entrepreneur, they had to face a lot more compared to the opposite gender; personally, professionally and financially.

\section{Stress}

Stress is the physiological and psychological response to a condition that threatens or challenges a person or requires some form of adaptation or adjustment. Individuals experience stress when they no longer have complete control over what happens in their lives. The entrepreneurial role in stress is the harmful physical

\section{Stress Causing Factors}

We live in a man's world. While difficult to accept, it is a stone-cold fact that puts women at a large disadvantage, especially when it comes to entrepreneurships and business which are traditionally seen as a male's work. Even though the number of women entrepreneurs is steadily rising, there are still a lot of obstacles they have to go through. In addition to the typical challenges faced by women all over the world, they have to fight against deep-rooted traditions and values as well. We have women excelling in every field today. Yet we see very few women entrepreneurs. It all comes down to the patriarchal society of today. Why is there this bias? Why are women, no matter how well qualified are expected to take a back seat? Are they perceived as a lifelong liability? They are supposed to take care of their husbands, children and in-laws while simultaneously completing their domestic duties in the house before looking at anything else. The demands from their family can stress out a woman who is considering starting up a business or have started a business and can make her rethink her worth as an entrepreneur. Even women who have gone past these problems face the task of balancing their work-life schedule as they are still expected to continue on with their domestic chores. They also have to face tough competition from the more educated and experienced males.

Societal discrimination also plays a part. The society tends to assume that females are not as competent when it comes to more risk-taking, aggressive and leadership-requiring roles. Women are socialized into being more reserved and soft-spoken and this is also what is expected of them. Religion and castes also come into play in societal discrimination; certain castes 
have more strict restrictions on females. A female from a rural area is even more likely to face such problems.

These values and beliefs can be observed in several situations. One example is that when it comes to raising capital, women entrepreneurs tend to have a harder time than male entrepreneurs. Investors generally give more consideration to a businessman than a businesswoman because they do not have as much confidence in a woman's business.

Safety and security is also another reason of stress and challenge faced by the women entrepreneurs. With the startling number of crimes against women, including harassment and rape, rising, female entrepreneurs are faced with the daunting decision of possibly risking their lives when taking on jobs that may require dedication and long hours into the night.

Still, we can see women entrepreneurs facing and conquering all these obstacles. Women in modern world have certainly come a long way when just years back, little of them were emerging into the business world. They have risen up from among the barely existing female business network and are part of the change for women. It is also comparatively far easier for the society to comprehend the notion of female entrepreneurs now. Female entrepreneurs are very essential to a country. Especially in developing countries like ours, they will be of much help to the economy. Also, entrepreneurships may be a possible financial solution to dependent women if given the right opportunities.

\section{Subdue the Stress, challenges and Issues}

* Increasing the ability of women to participate in the Labour force giving them that equal rights and treatment in the work place.

* Better educational facilities and schemes should be provided to the women.

Vocational training is given to improve their understanding in production process and production management. State Finance Corporations and financing respondents.

institutions should permit by statute to extend purely trade related finance to women entrepreneurs.

\section{Methodology}

\section{Findings}

District industries centre and Single window agencies should make use of assisting women in their trade and business guidance.

Governmental schemes to motivate women entrepreneurs to engage in small scale and largescale business ventures.

Adequate training program to improve their management skills.

Repeated gender sensitization programmers should be held to train financier to treat women with dignity and respect as persons in their own.

Initially a pilot study was done in which a tentative questionnaire was administered upon 15 selected women entrepreneurs of Mumbai to assess the reliability and validity of the statements. On the basis of the responses elicited, an elaborate questionnaire was finally prepared. The questionnaire consisted of 2 sections: general statistical information and job stress. The data was collected from 112 conveniently chosen woman entrepreneurs who run small scale commercial enterprises in Mumbai.

The survey participants comprised of 112 women entrepreneurs of Mumbai. Table 1 presents the results of the statistical analysis. Of the total sample, $47 \%$ were in the age group 40-50, 7\% were 20-30 years old, $40 \%$ were $30-40$ years old and $6 \%$ were above 50 years. Marital status varied- $91 \%$ were married and $9 \%$ were divorced. The majority of respondents had a bachelor degree $39 \%$ or completed higher secondary schooling $34 \%$. It was interesting to note that $41 \%$ of the respondents contributed more than $50 \%$ to the family income, followed by $40 \%$ whose contribution to family income was $20 \%-50 \%$ and $19 \%$ who contributed below 20\%. The years of experience of work were more than 8 years for 50\% respondents, $4-8$ years for $33 \%$ and below 4 years for $17 \%$ of the 


\begin{tabular}{|c|c|c|}
\hline Sl.no. & Variables & $\begin{array}{c}\text { Percentage } \\
\text { (approx) }\end{array}$ \\
\hline I & $\begin{array}{l}\text { Age (in years) } \\
20-30 \\
30-40 \\
40-50 \\
\text { Above } 50\end{array}$ & $\begin{array}{c}7 \\
40 \\
47 \\
6\end{array}$ \\
\hline II & $\begin{array}{l}\text { Marital Status } \\
\text { Married } \\
\text { Separated }\end{array}$ & $\begin{array}{c}91 \\
9\end{array}$ \\
\hline III & $\begin{array}{l}\text { Educational Qualification } \\
\text { Primary } \\
\text { Secondary } \\
\text { Higher secondary } \\
\text { Under graduate } \\
\text { Post Graduate }\end{array}$ & $\begin{array}{c}4 \\
19 \\
34 \\
39 \\
4\end{array}$ \\
\hline IV & $\begin{array}{l}\text { Years of experience } \\
\text { Below } 4 \\
4-8 \\
\text { Above } 8 \\
\end{array}$ & $\begin{array}{l}17 \\
33 \\
50 \\
\end{array}$ \\
\hline V1 & $\begin{array}{l}\text { Contribution to family } \\
\text { income (\%) } \\
\text { Less than 20\% } \\
20 \%-50 \% \\
\text { Ahoma }\end{array}$ & $\begin{array}{l}19 \\
40 \\
41\end{array}$ \\
\hline
\end{tabular}

\section{Main Sources of Stress}

Table 2:

\begin{tabular}{l|c}
\hline Source of stress & Mean (M) \\
\hline I find myself struggling between different roles & 4.17 \\
\hline I feel physically exhausted most of the time due to many duties and responsibilities & 3.94 \\
\hline I have a hard time balancing my work life with personal life. & 3.74 \\
\hline Shortage of time for social and religious functions makes me feel isolated. & 3.66 \\
\hline I feel strenuous to handle different types of customers. & 2.83 \\
\hline
\end{tabular}

Responsibilities and physical fatigue are the major sources of stress among women entrepreneurs. The survey result brings to light a fact that stereotyped attitude of the society towards women has ceased to be major stressor for women entrepreneurs. Further it was interesting to discover that women are receiving good support from their family members to take up entrepreneurship. Hence, very few of them reported that they are stressed due to lack of family support.

\section{Stress Management Strategies}

Table 3:

\begin{tabular}{l|c}
\hline Coping strategy & Mean (M) \\
\hline I tend to have a positive attitude and ignore the problem in the hope that it will go away. & 3.24 \\
\hline I manage to talk to friends/family members about my concerns. & 3.86 \\
\hline I plan my schedule daily, work on priorities and avoid unnecessary activities. & 3.63 \\
\hline I distract myself by listening to music & 4.01 \\
\hline I turn to prayers and listen to spiritual lectures to feel comfortable. & 3.12
\end{tabular}


It is observed that music related activities used more main source of stress. These factors are impediment for frequently to manage the stress among women the successful running of the business. Expectations of entrepreneurs. It is heartening to know that despite others and interest to do better than others is also complexity of work and various challenges; women another form of stress. The coping mechanism adopted have been coping with stress through music being on by the entrepreneurs in the study were communicating their high priorities to combat stress and second being with experienced people in the same field, their positive attitude. A high level of stress prompts communicating with subordinates, maintaining cool, to them to talk to their family and friends to discuss their take a break and delegating work.

concerns. Planning and prioritizing work, distracting oneself by turning to praying and spirituality are also common ways of coping with stress among women entrepreneurs.

\section{Heal Stress through Music}

- Listening to music each day can help women entrepreneurs relieve anxiety and improve overall health. They will feel more relaxed and calm when they listen to the song they love.

- Selection of the song based on their mood will help to elevate mood to the positive side. The soothing music will help them to relax and upbeat music will help them to improve their outlook on life.

- They should go out to watch and attend live music performances or concert.

- Should be lyrical and express their ways out by jotting down the feelings, without being worried about it being good or rhythmic.

- Use music with emotion in motion while exercising, walking jogging.

- Sing aloud in your own tone

\section{REFERENCES}

[1] Misra .S. and Shastr .I. Paper published in International Journal of Research and Scientific Innovation (IJRSI) titled : EMPIRICAL STUDY: IMPACT OF MUSIC ON PERSONALITY AND BEHAVIOUR OF CHILDREN: ISSN: 23212705.

[2] Misra .S. and Shastr .I.(2014).Paper published in Asian Journal Of Multidisciplinary Studies titled: THE ROLE OF MUSIC IN PSYCHOLOGICAL AND EMOTIONAL DEVELOPMENT : ISSN: 2321-8819

[3] Misra .S. and Shastr .I.(2014).Paper published in Journal of International Academic Research for Multidisciplinary (JIARM) titled : REFLECTION OF MUSIC ON THE PERSONALITY FROM INFANCY TO CHILDHOOD :ISSN: 2320 -5083

- Do not let the business be your priority try to enjoy life with music either in alone time or in traffic.

- Should embrace an active musical daily stress management routine.

\section{CONCLUSION}

[6] S Misra, I Shastri (2016), Psychological

The major stress of women entrepreneurs originates from work overload and physical fatigue. Further the result shows that music related activities used more frequently to manage the stress among women entrepreneurs. Women's involvement in business is not only for survival but also to satisfy their inner urge of creativity and prove their capabilities. Our society has certainly gone through a major social transformation. Women entrepreneurs' characteristics and skills are the

[4] P. Richard and M. Gary. (2011). The science \& Psychology of music performance: Creative strategies for teaching and learning. Oxford Scholarship

Online.

[5] Shveata Misra, Ina Shastri. Perceptual Experience and Auditory Inclination of Music According to the Sexuality. Psychology and Behavioral Sciences. Vol.5, No. , 2016, pp-7-11. Doi: $10.11648 / \mathrm{j} . p b s .20160501 .12$

Interpretation, Based On Statistical Analysis of Impact of Music on Rural and Urban People When Their Music Inclination Collides With Personality and Vice Versa - Comparative Study, International Journal of Indian Psychology, Volume 3, Issue 3, No. 7, DIP: 18.01.129/20160303, ISBN: 978-1-365- 12175-3 